\title{
100 let od přijetí Ústavní listiny Československé republiky. Historické, politické a právní souvislosti
}

Ve dnech 28. a 29. února 2020 se uskutečnila konference s názvem „100 let od přijetí Ústavní listiny Československé republiky - Historické, politické a právní souvislosti“. Konference byla připomínkou výročí přijetí první československé ústavní listiny a konala se v prostorách Valdštejnského paláce Senátu Parlamentu České republiky ve spolupráci Univerzity Karlovy s Historickým ústavem AV ČR a s podporou Senátu PČR. Uskutečnila se pod záštitou prvního místopředsedy Senátu Jiř́iho Růžičky, rektora UK Tomáše Zimy a předsedkyně Akademie věd ČR Evy Zažímalové.

Konferenci zahájila v pátek 28. února úvodní slova těch, kteří převzali nad akcí záštitu nebo jejich zástupců, a také proslovem jeho excelence Petera Weisse, velvyslance Slovenské republiky.

Po úvodních projevech následovala sekce s názvem Právní a historické souvislosti ústavy. Sekci zahájil svým vystoupením děkan Právnické fakulty prof. JUDr. Jan Kuklík, DrSc. Barvitě přiblížil politická jednání, která předcházela přijetí Ústavy 1920, a nastínil s tím spojené některé vybrané problémy, názorové rozpory a dohodnuté kompromisy. Širší mezinárodní i vnitrostátní historické souvislosti připojil doc. PhDr. Jan Němeček, DrSc., z Historického ústavu AV ČR. Blok zakončil svým exposé na téma Inspirativní vliv Ústavní listiny z roku 1920 na ústavní systém České republiky prof. JUDr. Aleš Gerloch, CSc., z Právnické fakulty UK.

Po zajímavé diskuzi k příspěvkům a krátké přestávce byl zahájen další blok s názvem „Vybrané části ústavy v historické retrospektivě do současnosti“. Zahájila jej doc. JUDr. Jana Reschová, CSc., z Právnické fakulty UK svým př́spěvkem na téma dynamika konstitucionalismu, ve kterém otevřela řadu otázek týkajících se současného ústavního vývoje. Svými úvahami o fenoménu parlamentarismu navázal JUDr. Ondřej Preuss, Ph.D., (PF UK). Věnoval se srovnání současného ústavního systému s prvorepublikovým modelem a hodnotil odlišnosti obou systémů. Blok zakončil JUDr. PhDr. Petr Mlsna, Ph.D., z Právnické fakulty UK svou přednáškou o pojetí moci výkonné v Ústavní listině 1920 jako inspiračním zdroji pro současný systém. Zároveň připojil analýzu problémů a možných nebezpečí, která s sebou toto propojení nese.

Př́spěvky opět rozvíŕily diskuzi nad některými přednesenými tématy. Po jejím zakončení a následné obědové pauze byla zahájena odpolední část pátečního programu konference. Jako první z odpoledního bloku nazvaného Vybrané právní a historické aspekty ústav do současnosti přednesl JUDr. Jiří Hřebejk, Ph.D., (PF UK) svůj př́íspěvek věnovaný úpravě srovnání územní samosprávy v Ústavě 1920 se současnou ústavní listinou. Následovalo vystoupení Mgr. Elišky Klimentové (PF UK) s názvem Nezávislé úráady jako 
trend současnosti. Sekci zakončil příspěvek doc. JUDr. PhDr. Marka Antoše, Ph.D., LL.M., (PF UK), který přítomným živým způsobem nastínil pozitiva i negativa, historický vývoj, současnou realitu a př́padné budoucí perspektivy volební povinnosti.

Po diskuzi následovala sekce s názvem Československo jako mnohonárodnostní stát, kterou otevřel příspěvek doc. PhDr. Zlatice Zudové-Leškové, CSc., (HIÚ), který byl orientován na vztahy Čechů a Slováků a doplnil tak podrobně širší kontext přijímání Ústavní listiny 1920. Následoval př́spěvek Mgr. Davida Hubeného, Ph.D., z Národního archivu pojednávající o vztahu Podkarpatské Rusi k Ústavě 1920, který byl přednesen v zastoupení. Posléze prezentoval JUDr. PhDr. René Petráš, Ph.D., (PF UK), který ve svém vystoupení rozebral postavení německé menšiny v novém státě. Blok zakončil navazující příspěvek PhDr. Evy Irmanové, CSc., (HIÚ) na téma vztahu mad’arské menšiny k československé ústavě.

Po skončení obsáhlé diskuze a krátkém občerstvení započal poslední blok pátečního programu. Ten tematicky doplňoval mezinárodní vlivy související s Ústavní listinou 1920. První příspěvek přednesený doc. PhDr. Jiřím Friedlem, Ph.D., DSc., (HIÚ) byl soustředěn na vývoj v Polsku. Navazoval příspěvek PhDr. Miroslava Šeptáka, Ph.D., (Filozofická fakulta Jihočeské univerzity) zaměřený na historické souvislosti vzniku rakouské ústavy z roku 1920. Posledním příspěvkem bloku a zároveň celého prvního dne konference bylo vystoupení prof. Alaina Soubigou (Université de la Sorbonne, Paříž), které komparativním způsobem pojednalo o možných vlivech francouzské ústavy na Československou ústavní listinu.

Druhý konferenční den, který z důvodu výročí připadl na sobotu dne 29. února, byl organizován méně tradičně, formou kulatého stolu. Účastníky tohoto kulatého stolu byli prof. JUDr. Jan Kuklík, DrSc., (PF UK), prof. PhDr. Ivan Halász, PhD., (MTA TK Jogtudományi Intézete, Budapešt'), prof. JUDr. Ladislav Vojáček, CSc., (Právnická fakulta Masarykovy univerzity), doc. Mgr. Jaroslav Šebek, Ph.D., (HIÚ) a doc. Dr. Ing. Ján Gronský, CSc., (PF UK). Po úvodní přednášce prof. Kuklíka byl program založen na diskuzních otázkách, které prof. Kuklík pokládal ostatním zúčastněným a tím moderoval vývoj debaty. Prof. Vojáček doplnil některé další aspekty př́pravy ústavní listiny, prof. Halász rozvedl politický význam Ústavy 1920. Doc. Šebek pohovořil o vztazích církve ke státu a s tím souvisejících úvahách o ústavní listině. Doc. Grónský pak průřrezově shrnul pozdější navazující ústavní vývoj.

Druhý konferenční den byl výjimečný nejen z toho důvodu, že poněkud nezvykle připadl na sobotu, ale také z důvodu avizované účasti řady studentů Právnické fakulty UK, kteří projevili o předmětnou problematiku zájem. Pro př́itomné studenty byl organizačním týmem pod vedením prof. Kuklíka připraven vědomostní kvíz vycházející obsahově $\mathrm{z}$ témat rozebíraných u kulatého stolu.

Po diskuzi přítomných konferujících se studenty byla sobotní část konference završena komentovaná prohlídkou Senátu.

Celá akce byla nejen důstojným připomenutím významného výročí Ústavy 1920, ale také platformou pro sdílení poznatků, náhledů a závěrů z oblasti právní historie, obecné historie a ústavního práva. Jako taková bude (doufejme) impulsem pro další vědeckou práci, propojování různých př́stupů k tématu a posouvání hranic odborného poznání.

Lukáš Blažek

Tereza Blažková

doi: 10.14712/2464689X.2020.25 